\title{
Growth rates of interface-feeding polychaetes: combined effects of flow speed and suspended food concentration
}

\author{
Brian T. Hentschel*, Amy A. Larson \\ Department of Biology, San Diego State University, 5500 Campanile Drive, San Diego, California 92182-4614, USA
}

\begin{abstract}
Most spionid polychaetes switch from deposit feeding to suspension feeding as the current speed and the flux of suspended food particles increase. Previous experiments testing the effects of flow on the growth rates of facultative, interface feeders have been limited to a single concentration of suspended food. We performed an experiment in counter-rotating annular flumes set to one of 3 flow speeds and 2 concentrations of suspended microalgae. This design allowed the horizontal flux of algae (i.e. concentration multiplied by current speed) to be manipulated by 2 independent means. The relative growth rates of Polydora cornuta and Streblospio benedicti were measured during a series of $3 \mathrm{~d}$ runs in replicate flumes set to each of the 6 food-flow treatments. Sediment collected from the worms' field site was added to each flume as a food source for deposit-feeding worms. The 3 flow speeds $\left(U_{5 \mathrm{~mm}}=3,6\right.$, or $12 \mathrm{~cm} \mathrm{~s}^{-1}$, where $U_{5 \mathrm{~mm}}=$ velocity measured $5 \mathrm{~mm}$ above bottom) were all slower than the sediment's critical erosion velocity $\left(U_{5 \mathrm{~mm}}=13 \mathrm{~cm} \mathrm{~s}^{-1}\right.$; shear velocity $U_{*}=0.9 \mathrm{~cm}$ $\left.\mathrm{s}^{-1}\right)$. P. cornuta grew significantly faster as flow increased in the lower algal concentration, but not in the higher one. The higher algal concentration led to faster growth of $P$. cornuta at the 2 slower flows, but there was no effect of algal concentration at the fastest flow speed. Overall, the growth rate of $P$. cornuta increased as the horizontal flux of suspended food increased up to a value that led to a maximal growth rate, regardless of whether the flux of suspended food was manipulated by flow speed or by algal concentration. In contrast, $S$. benedicti did not show significant relationships between growth rate and either flow speed, algal concentration, or the overall flux of suspended food. The data demonstrate that the juvenile growth rates of some interface-feeding spionids, such as $P$. cornuta, can be tied strongly to hydrodynamic conditions that favor passive suspension feeding, while the growth rates of other interface-feeding spionids, such as $S$. benedicti, can be less sensitive to flow.
\end{abstract}

KEY WORDS: Benthic boundary layer $\cdot$ Deposit feeding $\cdot$ Flume $\cdot$ Growth rate $\cdot$ Polydora $\cdot$ Spionid polychaete $\cdot$ Streblospio $\cdot$ Suspension feeding

Resale or republication not permitted without written consent of the publisher

\section{INTRODUCTION}

Benthic invertebrates are commonly classified into a variety of feeding guilds or functional groups such as carnivores, herbivores, deposit feeders, or suspension feeders (e.g. Hunt 1925, Rhodes 1974, Fauchald \& Jumars 1979). Such classifications are often overly simplistic and can lead to questionable interpretations about the patterns of community structure in soft sediments (Snelgrove \& Butman 1994). Applying general functional groups to explain patterns of community structure is especially problematic when individual species alter their feeding behavior or mobility in response to ecological variables such as intra- and interspecific density (Dauer et al. 1981, Levin 1981, Olafsson 1986, Taghon 1992), exposure to predators (Levinton 1971, Lindsay \& Woodin 1995), or hydrodynamic conditions (Miller et al. 1992, Powers \& Peterson 2000, Stocks 2002).

Perhaps the most common alteration of feeding behavior occurs in several polychaete and bivalve species that facultatively switch between deposit feeding 
and suspension feeding in response to hydrodynamic conditions (e.g. Brafield \& Newell 1961, Taghon et al. 1980, Olafsson 1986, Levinton 1991, Miller et al. 1992, Taghon \& Greene 1992, Bock \& Miller 1996, 1997). While the nutrition and growth of many suspension feeders is strongly influenced by water flow and the horizontal flux of suspended food particles (Muschenheim 1987, Frechette et al. 1989, Judge et al. 1992, Eckman \& Duggins 1993), the nutrition of facultative 'interface feeders' (Dauer et al. 1981) will be influenced by both the quality and quantity of suspended and deposited food, as well as by the hydrodynamic conditions in the benthic boundary layer. Furthermore, any ecological or geochemical effects that result from the feeding, tube-building, and bioturbation activities of interface-feeding microphages (e.g. Aller 1982, Aller \& Yingst 1985, Thrush et al. 1996) will be indirectly influenced by water flow. In particular, flows that favor the growth, reproduction, and high population density of interface-feeding benthos are likely to have far-reaching ecological and geochemical implications in soft-sediment communities.

Growth is perhaps the most comprehensive measure of an individual's nutrition, especially for prereproductive juveniles, and is central to any argument linking feeding behaviors to community structure (e.g. Rhodes 1974). Although the effects of flow on the feeding behaviors of interface-feeding benthos have been well documented, few studies have measured the growth rates of facultative interface feeders in different flow regimes. Olafsson (1986) measured similar growth rates of the interface-feeding bivalve Macoma balthica in a sandy habitat where suspension feeding dominated and in a muddy habitat where deposit feeding dominated. The growth rates of interface-feeding spionid polychaetes generally increase with increasing flow speed in laboratory flumes (Taghon 1992, Taghon \& Greene 1992, Hentschel 2004). Interpreting the effects of flow speed on the growth of suspension feeders can, however, be problematic. In correlative field studies, flow is often confounded with other environmental variables that can affect an animal's growth, especially the concentration or quality of suspended food particles. Manipulative experiments in laboratory flumes or flow pipes aim to control the relevant variables, but it can be difficult to maintain constant concentrations and qualities of suspended food particles across different flow regimes for the extended time periods necessary to measure significant changes in body size, even when natural suspensions are pumped from the field (e.g. Taghon \& Greene 1992, Eckman \& Duggins 1993, Lenihan et al. 1996).

Hentschel (2004) measured the growth rates of spionid polychaetes in laboratory flumes in which the concentration of suspended microalgae added to the flumes was monitored closely during $3 \mathrm{~d}$ manipulations of flow speed. The 2 species tested, Polydora cornuta and Streblospio benedicti, had very rapid relative growth rates (up to 0.6 and $0.3 \mathrm{~d}^{-1}$ for small juveniles of each species, respectively) that increased with increasing flow up to a plateau at the 2 fastest flow speeds tested. Hentschel (2004) offered 2 alternative explanations of the asymptote at the fastest flow speed: (1) As flow speed and the horizontal flux of suspended food particles increased, worms eventually reached a physiologically maximal rate of growth or (2) the rates of successful particle capture decreased at faster flows.

Here, we present the results of an experiment that simultaneously manipulated flow speed and the concentration of suspended food particles to help clarify these alternative hypotheses by manipulating both components of the horizontal flux of suspended food (i.e. particle concentration multiplied by current speed). We were, therefore, able to decouple the flux of suspended food particles from flow speed. Few studies aimed at testing the effects of flow speed on the feeding and growth of suspension feeders have manipulated both flow and the concentration of suspended food as independent variables (e.g. Wildish et al. 1992, Lenihan et al. 1996). Because interface feeders can shift between suspension feeding and deposit feeding, our flume experiment also included a layer of fieldcollected sediment as food for deposit-feeding worms and was restricted to slow and moderate flow speeds that do not erode fine sands. The flumes provided controlled mesocosms in which we were able to measure how small changes in flow speed and the concentration of suspended food combine to affect the growth rates of 2 common species of interface-feeding polychaetes.

\section{MATERIALS AND METHODS}

Preliminary set-up of flume experiments. The experiment was conducted in the counter-rotating annular flumes at Rutgers University's Institute of Marine and Coastal Sciences. These flumes have been described in detail elsewhere (Hentschel 2004, Hunt 2004). Four identical counter-rotating annular flumes allow multiple flumes to be run simultaneously during a controlled experiment.

The procedures for collecting live spionid polychaetes, measuring their body sizes, and transplanting the worms into the flumes are described in detail in Hentschel (2004). Briefly, Polydora cornuta and Streblospio benedicti were collected from an intertidal sandflat at Shark River Island, NJ, USA, by sieving surficial sediments in the field ( 1 and $0.5 \mathrm{~mm}$ mesh), and worms were sorted to species in the laboratory over a period of 1 to $2 \mathrm{~d}$. Sorted worms were maintained in 
glass bowls of $5 \mu \mathrm{m}$-filtered seawater at $15^{\circ} \mathrm{C}$. To allow sorted worms to construct sediment tubes, a few drops of silty seawater that had been frozen and thawed were added to each bowl containing 25 to 50 worms. Sorted worms were either used in a run of the flume experiment or discarded no longer than $3 \mathrm{~d}$ after they had been collected from the field.

Prior to each experimental run, sorted worms were anesthetized in $3 \% \mathrm{MgCl}_{2}$ and divided into 2 length classes for each species. The body-length classes for Polydora cornuta were 1 to $4 \mathrm{~mm}$ and 6 to $9 \mathrm{~mm}$. This species typically becomes sexually mature at a body length of $\sim 1 \mathrm{~cm}$ (Hentschel 1998a, 2004). The classes for Streblospio benedicti were 0.5 to $2.7 \mathrm{~mm}$ and 3.5 to $5.5 \mathrm{~mm}$. This species begins producing gametes at a body length of $\sim 5 \mathrm{~mm}$ (B. T. Hentschel pers. obs.). The small classes included juveniles that were extremely small and often had remnants of their larval pigmentation (e.g. Blake 1969). Length measurements were made by video microscopy using a Wild stereomicroscope, a Sony CCD video camera, and NIH Image software. In addition to measuring each individual's total body length, we measured its body width at 5 locations between the anterior and posterior ends. Length and width measurements were used to calculate each individual's body volume at the start of an experimental run, modeling the worm as a series of 4 conical frustums. The volume of each frustum is calculated as:

$$
V=\frac{\pi}{3} \times L \times\left[\left(\frac{W_{1}}{2}\right)^{2}+\left(\frac{W_{1}}{2} \times \frac{W_{2}}{2}\right)+\left(\frac{W_{2}}{2}\right)^{2}\right]
$$

where $V$ is the volume of the frustum, $L$ is the length of the frustum, and $W_{1}$ and $W_{2}$ are the 2 width measurements at each end of the frustum. The entire body volume of a worm is calculated by summing the volumes of the 4 conical frustums.

After an individual worm was measured, it was briefly transferred from $3 \% \mathrm{MgCl}_{2}$ to filtered seawater and then placed in a small, numbered vial containing sediment. The vials $(2 \mathrm{~cm}$ high $\times 1.4 \mathrm{~cm}$ diam.) were constructed from $5 \mathrm{ml}$ pipet tips with Hot Melt Glue sealing one open end. The sediment had been collected from the field site, frozen and thawed, sieved in seawater to remove particles greater than $0.3 \mathrm{~mm}$, and frozen and thawed again prior to being added to vials. A worm typically built a sediment tube inside its vial within $1 \mathrm{~h}$. Vials containing worms were placed in holes drilled within $1.3 \mathrm{~cm}$ thick PVC slabs $(\sim 15 \times$ $30 \mathrm{~cm}, \mathrm{~W} \times \mathrm{L})$. Each PVC slab contained 20 to 30 vials that were separated horizontally by at least $2 \mathrm{~cm}$. Locations of individual vials within and among slabs were random. Slabs containing vials were then placed in a seawater table $\left(15^{\circ} \mathrm{C}\right.$, salinity $=30 \%$ ). All 60 to 120 worms for a single experimental run were measured, implanted in vials, and placed in the seawater table during a single $12 \mathrm{~h}$ period. Worms acclimated to vials overnight in the seawater table for an additional 15 to $18 \mathrm{~h}$ prior to being implanted in the flumes.

The day following measurement and acclimation to vials, PVC slabs containing vials were implanted into a $2 \mathrm{~cm}$ deep layer of silica sand ( $\sim 0.75 \mathrm{~mm}$ diam.) that had been spread evenly throughout a flume. PVC slabs were planted in a single section of the flume, roughly one-eighth of the channel's total circumference. Vials occupied the center $10 \mathrm{~cm}$ of the channel. The sand layer in the entire flume was smoothed to a height of $2 \mathrm{~cm}$ so the top edges of the vials were flush with the sand-water interface.

After vials were implanted in the sand layer, the flume was filled with $5 \mu \mathrm{m}$-filtered seawater to achieve a $28 \mathrm{~cm}$ deep water column. A thin layer ( 2 mm thick) of field-collected sediment was then deposited above the sand. This was accomplished by sieving $(1 \mathrm{~mm}$ mesh) a 21 bucket of field-collected sediment, which had been frozen and thawed, into the flume's water column. The slurry settled overnight, forming the smooth $\sim 2 \mathrm{~mm}$ layer above the sand layer and vials. Flow treatments began the following morning, 15 to $18 \mathrm{~h}$ after the field-collected sediment was added.

The total time period for the measurement of worms' initial body sizes, acclimation to vials, and acclimation to the flumes was $48 \mathrm{~h}$. Hentschel (2004) measured relatively negligible relative growth rates $\left(4 \% \mathrm{~d}^{-1}\right)$ during the still-water acclimation period.

Manipulations of flow and suspended food. Individuals of Polydora cornuta and Streblospio benedicti that had been measured and acclimated to flumes were exposed to one of 3 constant, unidirectional flow speeds and one of 2 concentrations of suspended microalgae in a fully factorial design. Temperature was controlled at $20^{\circ} \mathrm{C}$. For each experimental run, 2 or 3 annular flumes were run simultaneously for $3 \mathrm{~d}$. PVC slabs containing vials of individual worms were randomly assigned to each flume in a run. Each of the 6 flow-food treatments was replicated 5 or 6 times. The unequal replication resulted because of limited availability of worms during some field collections and due to an electrical storm that damaged the flumes' control system during 1 run of 3 flumes. In total, the experiment included 33 flumes distributed among 14 runs between May and October 2000. Flow and food treatments were randomly assigned to each of the flumes in a completely randomized design, with the added constraint that any 2 flumes in a single run would not be assigned the same flow-food treatment.

Typically, each flume contained 10 to 15 small Polydora cornuta, 10 to 15 large P. cornuta, 5 to 10 small Streblospio benedicti, and 5 to 12 large $S$. benedicti at the start of the experiment. Because the availability of some species-size classes was limited in some field 
collections, one of the 4 classes was occasionally not implanted into one or more of the flumes in a given run. Most of the 4 species-size classes were implanted into 4 or 5 of the replicate flumes for each of the 6 different flow-food treatments, but there were 2 cases where a species-size class was present in only 3 of the replicate flumes and a few cases where a species-size class was present in all 6 replicate flumes (see Results for exact sample sizes of each treatment).

The 3 flow treatments were $U_{5 \mathrm{~mm}}=3,6$, or $12 \mathrm{~cm} \mathrm{~s}^{-1}$, where $U_{5 \mathrm{~mm}}$ denotes the mean horizontal velocity measured with a laser-doppler velocimeter positioned $0.5 \mathrm{~cm}$ above the sediment-water interface. Hentschel (2004) reports flume-rotation settings and values for the shear velocity $\left(U_{*}\right)$ for these flow treatments. The fastest flow treatment $\left(U_{5 \mathrm{~mm}}=12 \mathrm{~cm} \mathrm{~s}^{-1}\right)$ was slower than the critical erosion velocity of the sediment added to the flumes (Hentschel 2004). Hentschel (2004) previously showed that the growth rates of Polydora cornuta and Streblospio benedicti increased in response to sediment erosion. We explicitly limited this experiment to non-erosional speeds so that the concentrations of suspended food would be controlled.

To provide and control suspended food particles, a nonliving algal slurry (C-6 Slurry, Coast Seafoods) was added to each flume. This slurry is composed of several phytoplankton genera, including Thalassiosira, Skeletonema, Chaetoceros, and Isochrysis. The slurry has a cell concentration on the order of $10^{9} \mathrm{cells} \mathrm{ml}^{-1}$, a particulate $\mathrm{C}$ concentration of $35 \mathrm{~g} \mathrm{l}^{-1}$, and a particulate $\mathrm{N}$ concentration of $7 \mathrm{~g} \mathrm{l}^{-1}$ (Carlo-Erba analysis of diluted samples filtered onto pre-combusted GF/C filters). A pulse of the algal slurry was added to each flume each day during a $3 \mathrm{~d}$ experimental run. The volumes of algal slurry added each day were designed to create distinct high-food and low-food conditions throughout the $3 \mathrm{~d}$ duration of an experimental run (Table 1). To determine the actual concentrations of suspended food, the water in each flume was sampled $30 \mathrm{~min}$

Table 1 . The volumes of algal slurry added to a flume during each day of the $3 \mathrm{~d}$ experimental run. Algal additions were based on Hentschel (2004) and results of pilot studies designed to create 2 distinct concentrations of suspended food throughout the $3 \mathrm{~d}$ run. Flow was initiated at $0 \mathrm{~h}$ and terminated at $72 \mathrm{~h}$

\begin{tabular}{|lcc|}
\hline $\begin{array}{l}\text { Food } \\
\text { treatment }\end{array}$ & $\begin{array}{c}\text { Time since } \\
\text { flow initiation (h) }\end{array}$ & $\begin{array}{c}\text { Volume of algal } \\
\text { slurry added (ml) }\end{array}$ \\
\hline High food & 1 & 15 \\
& 25 & 5 \\
Low food & 49 & 7.5 \\
& 1 & 7.5 \\
& 25 & 2.5 \\
49 & 2.5 \\
\hline
\end{tabular}

before and 30 min after each addition of algae by draining through the syringe-needle port in the flume's inside wall and filtering onto pre-combusted GF/C filters for measurement of particulate $\mathrm{C}$ and $\mathrm{N}$ concentrations. In addition, a water sample was taken a few minutes before the $72 \mathrm{~h}$ experimental run ended. In total, we made 7 measurements of particulate $\mathrm{C}$ and $\mathrm{N}$ concentrations for each flume during its $3 \mathrm{~d}$ run. We used these measurements to compute an average particulate-nitrogen concentration in each flume during the $3 \mathrm{~d}$ run.

At the end of a $3 \mathrm{~d}$ run, the PVC slabs and the vials containing the pre-measured worms were recovered from the flumes (Hentschel 2004). During the entire 6 mo experiment involving 33 flumes, 911 of the 1214 pre-measured worms implanted in the flumes were recovered. Each recovered individual was re-measured to calculate its body volume at the end of its $3 \mathrm{~d}$ run. Relative growth rates (RGR) were calculated according to Fisher (1920) as:

$$
\mathrm{RGR}=\frac{\left[\ln \left(V_{\mathrm{f}}\right)-\ln \left(V_{\mathrm{i}}\right)\right]}{\text { time }}
$$

where $V_{\mathrm{f}}$ and $V_{\mathrm{i}}$ are measurements of each individual's final and initial body volume, respectively.

Data were analyzed in several ways. The experiment was designed to test specific predictions following the results of Hentschel (2004), and our analyses of each species and size class within a species were planned $a$ priori. To avoid pseudoreplication (Hurlbert 1984), statistical comparisons involving the effects of flow or food treatments used the mean RGR for each speciessize class within each flume. First, we tested for differences in RGR due to flow. Hentschel (2004) performed a similar flow experiment at a single food concentration that was comparable to the high-food condition in our experiment. Here, we determined whether the effects of flow on RGR also occurred at a lower concentration of suspended food. We tested the flow effect separately for each of the 2 concentrations of suspended food by 1-way ANOVA. We then directly tested the effect of food concentration on RGR by comparing the high-food and low-food treatments at each of the 3 flow speeds by $t$-tests. Finally, we compared RGR to the horizontal flux of suspended food, which we varied in the flumes by manipulating both flow speed and food concentration. In addition to combining the food and flow manipulations into a common parameter, this comparison accounts for the fact that the concentration of suspended microalgae varied somewhat among the 5 to 6 replicate flumes in a given flow-food treatment. The average near-bottom flux of particulate nitrogen for each flume was estimated by multiplying a flume's average particulate nitrogen concentration by $U_{5 \mathrm{~mm}}$ for each flume. 


\section{RESULTS}

The daily additions of nonliving algal slurry created 2 distinct high-food and low-food concentrations throughout the duration of the $3 \mathrm{~d}$ experimental runs in the flumes (Fig. 1). The filtration of water samples before and after each daily addition of algae also revealed that the greater volumes added (Table 1) led to greater short-term increases in the concentration of suspended particulate nitrogen (Fig. 1). As Hentschel (2004) observed, the concentration of suspended food declined over time, and there was a trend toward more deposition of suspended algae at faster flows (Fig. 1). This is especially evident when comparing the average particulate nitrogen concentrations among the 3 velocities (Fig. 2); however, the trend was not significant during this experiment for either concentration of algae (Fig. $2 ; F_{2,13}=1.444, \mathrm{p}=0.271$ and $F_{2,14}=2.599$, $\mathrm{p}=0.110$ for the low-food and high-food treatments, respectively). The overall mean average particulate nitrogen concentration of the 17 high-food flumes was $0.26 \mathrm{mg} \mathrm{N} \mathrm{I}^{-1}$, and that of the 16 low-food flumes was $0.17 \mathrm{mg} \mathrm{N}^{-1}$ (Fig. 2). Hentschel (2004) reported particulate nitrogen concentrations ranging between 0.1 to $0.6 \mathrm{mg} \mathrm{N} \mathrm{l}^{-1}$ (mean $=0.34$ ) in water samples collected from the Shark River Island field site during the summer and fall months. The achieved average concentrations of particulate nitrogen suspended in the water of the flumes are, therefore, within the range of field conditions but below average.

In general, the relative growth rates (RGR) of the small length class of Polydora cornuta were affected by

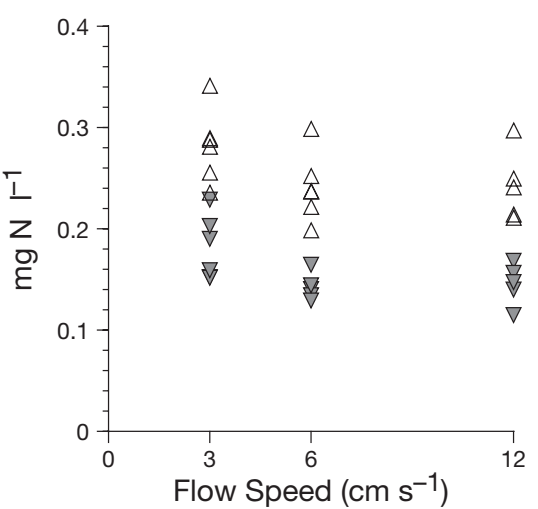

Fig. 2. Average particulate nitrogen concentrations in each of the 33 flumes run during the 6 mo experiment. Each plotted symbol is the average of 7 samples collected over time from an individual flume during its $72 \mathrm{~h}$ run (see Fig. 1). Shaded symbols indicate replicate flumes within the low-food treatment; open symbols indicate replicate flumes within the highfood treatment. Current velocities were measured $5 \mathrm{~mm}$ above the sediment-water interface. There is a trend toward decreased concentrations of suspended particulate nitrogen as velocity increased, but this trend was not statistically significant $(\mathrm{p}>0.1)$

both increases in flow and increases in the concentration of suspended food, but as expected a priori, there were interactions between these variables (Fig. 3A). Small $P$. cornuta grew significantly faster as flow velocity increased in the low-food treatment (Fig. $3 \mathrm{~A}_{i} F_{2,11}=$ $14.881, \mathrm{p}<0.001)$, but the effect of flow on the RGR of small $P$. cornuta did not vary significantly $(\alpha=0.05)$ with flow in the high-food treatment (Fig. $3 \mathrm{~A}_{i} F_{2,12}=$ $3.091, \mathrm{p}=0.081$ ). Small $P$. cornuta grew significantly faster in the high-food treatment relative to the low-food treatment at $U_{5 \mathrm{~mm}}=3$ and $6 \mathrm{~cm} \mathrm{~s}^{-1}$ ( $t$-tests, $\mathrm{p}=0.046$ and 0.009 , respectively), but there was no food-related difference in the RGR of small $P$. cornuta at the fastest flow of $U_{5 \mathrm{~mm}}=12 \mathrm{~cm} \mathrm{~s}^{-1}$ (Fig. 3A).

The larger length class of Polydora cornuta showed similar trends (Fig. 3B). Large P. cornuta grew significantly faster as flow increased in the low-food treatment (Fig. 3B; $F_{2,9}=10.666, \mathrm{p}=0.004$ ), but the effect of flow on the RGR of large $P$. cornuta was not significant in the high-food treatment (Fig. 3B; $F_{2,11}=2.544, \mathrm{p}=0.124$ ). There was a significant difference in the RGR of large $P$. cornuta due to the concentration of suspended food at $U_{5 \mathrm{~mm}}=3 \mathrm{~cm} \mathrm{~s}^{-1}$ (Fig. 3B; $t$-test, $\mathrm{p}=0.046$ ), but not at either of the 2 faster flows ( $t$-tests, $p>$ 0.16 in each comparison).

Plotting RGR versus the average flux of particulate nitrogen $5 \mathrm{~mm}$ above the bottom clearly shows how flow speed and the

Fig. 1. Mean concentrations of suspended particulate nitrogen in each of the 6 food-flow treatments over time. Water samples were filtered and analyzed before and after each daily addition of microalgae (at 1, 25, and $49 \mathrm{~h}$ after the initiation of flow) and at the end of each flume's $72 \mathrm{~h}$ run (see Table 1). Each plotted symbol represents the mean particulate nitrogen concentration of 5 or 6 replicate flumes for each food-flow treatment. Current velocities were measured $5 \mathrm{~mm}$ above the sediment-water interface and are distinguished by different symbol shapes 

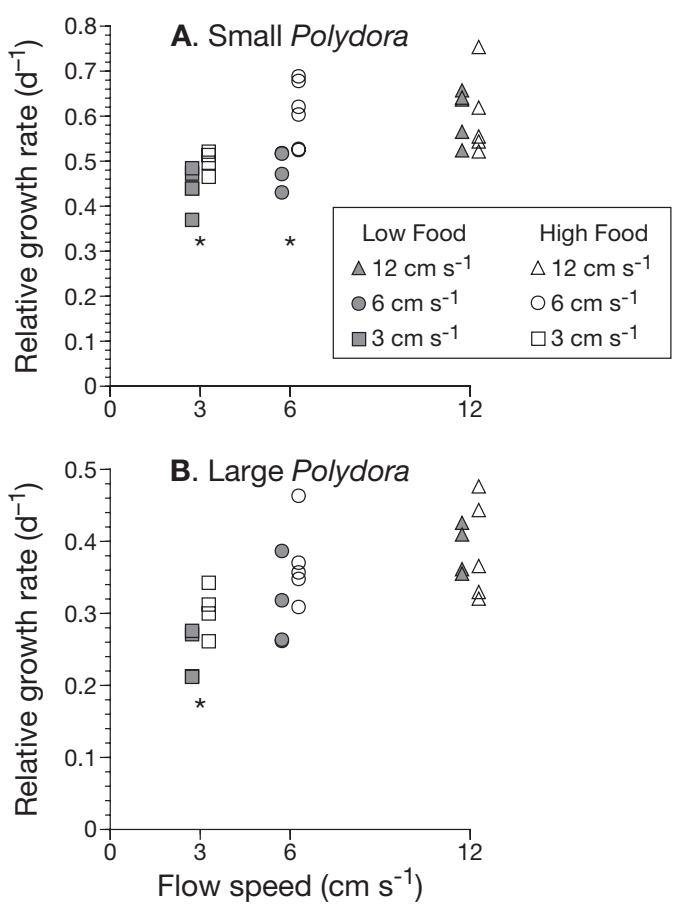

Fig. 3. Relative growth rates (RGR) of Polydora cornuta versus flow speed. (A) small size class of $P$. cornuta (initial length $=$ 1 to $4 \mathrm{~mm}$ ) and (B) large size class of $P$. cornuta juveniles (initial length $=6$ to $9 \mathrm{~mm}$ ). Each plotted symbol represents the mean relative growth rate of $\sim 10$ to 15 individual worms from a single flume set to 1 of 3 current velocities and 1 of 2 concentrations of suspended microalgae (the SD of any mean RGR from a single flume was $~ 0.10$ ). Each of the 6 food-flow treatments was replicated by 4 to 6 independent flumes run during the 6 mo experiment. Symbols for the 2 food treatments are plotted slightly to the left or right of the exact value of each flow speed $\left(U_{5 \mathrm{~mm}}=3,6\right.$, or $\left.12 \mathrm{~cm} \mathrm{~s}^{-1}\right)$ to aid in distinguishing data from the 2 food treatments. Asterisks indicate significant differences between RGR in the high-food and low-food flumes at a given speed $(t$-tests, $\mathrm{p}<0.05)$. The RGRs of each size class were significantly faster as flow increased in the low-food concentration ( $p<0.01$ for each size class) but did not vary significantly with flow in the high-food concentration ( $p>0.08$ for each size class)

concentration of suspended food combine to influence the growth of Polydora cornuta. For both size classes, RGR increased as the flux of particulate nitrogen increased (Fig. $4 ; F_{1,27}=14.966, \mathrm{p}<0.001$ and $F_{1,24}=$ 13.681, $\mathrm{p}=0.001$ for small and large worms, respectively). The relationship between RGR and the flux of suspended food appears to reach an asymptote at RGR $\sim 0.6 \mathrm{~d}^{-1}$ for small $P$. cornuta and $\sim 0.4 \mathrm{~d}^{-1}$ for large $P$. cornuta (Fig. 4). These maximal RGRs are reached at $U_{5 \mathrm{~mm}}=6 \mathrm{~cm} \mathrm{~s}^{-1}$ in the high-food treatment and at $U_{5 \mathrm{~mm}}$ $=12 \mathrm{~cm} \mathrm{~s}^{-1}$ in the low-food treatment, when the average flux was $\sim 5$ to $6 \mathrm{mg} \mathrm{N} \mathrm{cm}^{-2} \mathrm{~h}^{-1}$ (Fig. 4).

In general, the relative growth rates of Streblospio benedicti were not affected by flow, the concentration of suspended microalgae, or the flux of suspended particu-
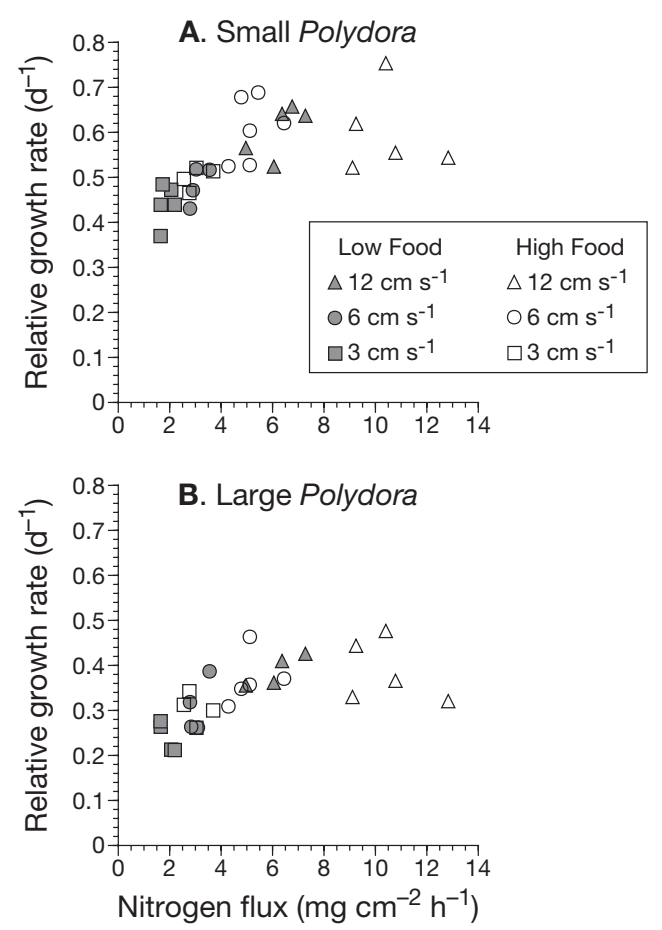

Fig. 4. Relative growth rates (RGR) of Polydora cornuta versus the calculated average flux of particulate nitrogen $5 \mathrm{~mm}$ above the sediment-water interface. (A) Small size class, (B) large size class of $P$. cornuta juveniles. Each plotted symbol represents the mean RGR of $\sim 10$ to 15 individual worms from a single flume (see Fig. 3). RGR of each size class increased with increasing flux of suspended food ( $p \leq 0.001$ for each size class)

late nitrogen. In the low-food treatment, small $S$. benedicti showed a trend toward slightly slower growth as flow speed increased, but this trend was not statistically significant (Fig. 5A $F_{2,9}=3.793, p=0.064$ ). In the highfood treatment, the RGR of small $S$. benedicti showed no relationship with flow speed (Fig. 5A; $F_{2,11}=0.301, \mathrm{p}=$ $0.746)$. There was also no significant difference in the RGR of small $S$. benedicti due to the concentration of suspended food at any of the 3 flow velocities (Fig. 5A; $t$-tests, $\mathrm{p}>0.3$ in each comparison). The larger $S$. benedicti did not show any significant relationships between RGR and flow in either the low-food treatment (Fig. 5B; $F_{2,11}=1.285, \mathrm{p}=0.315$ ) or the high-food treatment (Fig. $5 B_{;} F_{2,7}=0.105, p=0.902$ ). There was also no significant difference in the RGR of large $S$. benedicti due to the concentration of suspended food at any of the 3 flow velocities (Fig. 5B; $t$-tests, $p>0.7$ in each comparison). Finally, neither small nor large $S$. benedicti showed a significant relationship between RGR and the flux of suspended particulate nitrogen (Fig. $6 ; F_{1,24}=$ $0.027, \mathrm{p}=0.870$ and $F_{1,22}=0.181, \mathrm{p}=0.674$ for small and large worms, respectively). 

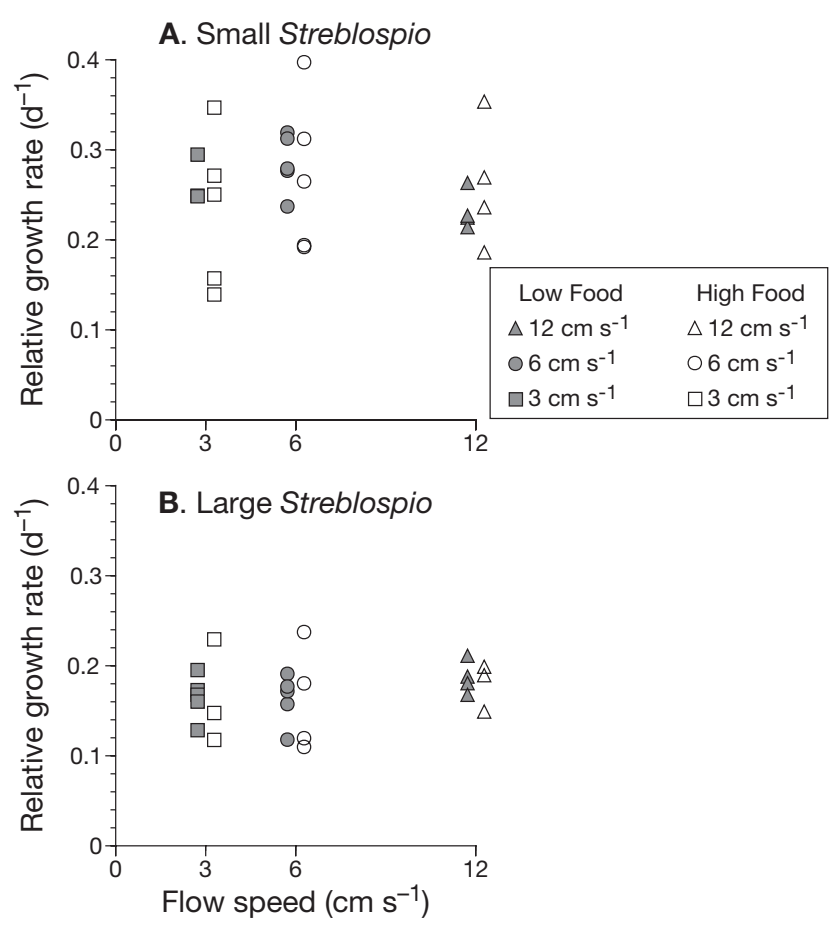

Fig. 5. Relative growth rates (RGR) of $S$. benedicti versus flow speed. The format is the same as Fig. 3. (A) Small size class of Streblospio benedicti (initial length $=0.5$ to $2.7 \mathrm{~mm}$ ) and (B) large size class of $S$. benedicti (initial length $=3.5$ to $5.5 \mathrm{~mm}$ ). Each plotted symbol represents the mean RGR of $\sim 5$ to 12 individual worms from a single flume set to 1 of 3 current velocities and 1 of 2 concentrations of suspended microalgae (the SD of any mean RGR from a single flume was $\sim 0.07$ ). Each of the 6 food-flow treatments was replicated by 3 to 5 independent flumes run during the 6 mo experiment. The RGRs of either size class of $S$. benedicti did not vary significantly with flow at either food concentration $(p>0.06)$. The RGR of $S$. benedicti did not differ significantly between the 2 food treatments at any of the 3 flow speeds ( $p>0.3$ )

\section{DISCUSSION}

Hentschel (2004) performed similar flume experiments and showed that the growth rates of Polydora cornuta and, to a lesser extent, Streblospio benedicti increased significantly in response to sediment resuspension and the transport of suspended microalgae. The previous experiment in which the flux of suspended microalgae was manipulated by varying flow speed included only a single concentration of microalgae in the flumes, and the growth rates of $P$. cornuta and $S$. benedicti were correlated with the flux of suspended food only at fluxes less than $\sim 6 \mathrm{mg} \mathrm{N} \mathrm{cm}^{-2} \mathrm{~h}^{-1}$ when $U_{5 \mathrm{~mm}} \leq$ $6 \mathrm{~cm} \mathrm{~s}^{-1}$ (Hentschel 2004). Hentschel (2004) suggested 2 alternative explanations for the plateau in growth rates at fluxes greater than $\sim 6 \mathrm{mg} \mathrm{N} \mathrm{cm}{ }^{-2} \mathrm{~h}^{-1}$ : (1) the worms reached a physiologically maximal growth rate (i.e. growth was no longer limited by the supply of food) or

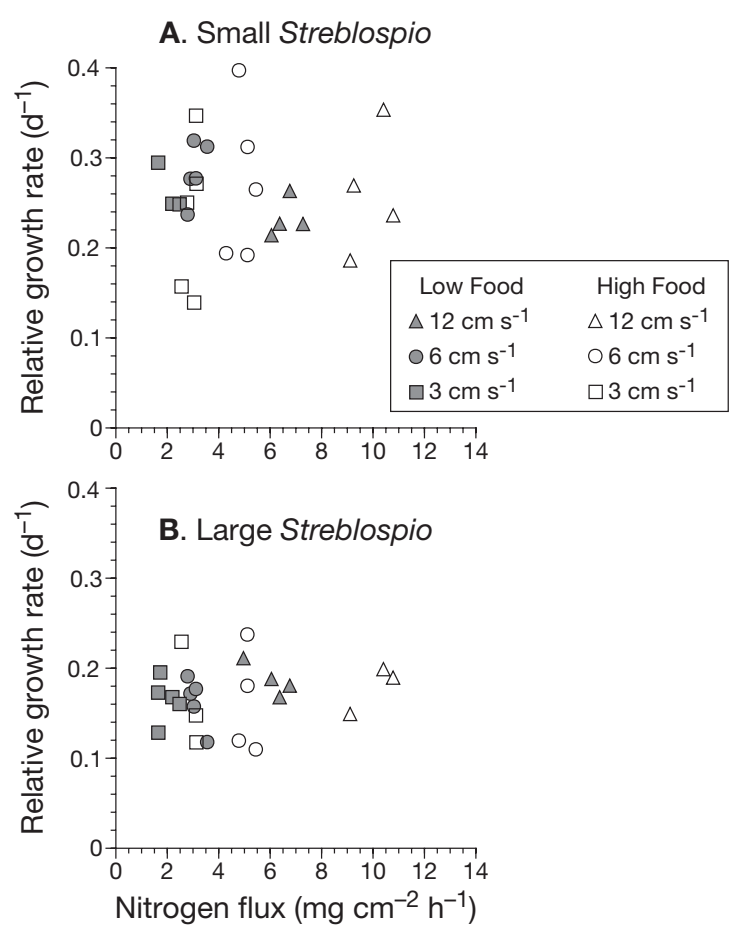

Fig. 6. Relative growth rates (RGR) of Streblospio benedicti versus the calculated average flux of particulate nitrogen $5 \mathrm{~mm}$ above the sediment-water interface. The format is the same as Fig. 4. (A) Small size class, (B) large size class of $S$. benedicti. Each plotted symbol represents the mean RGR of $\sim 5$ to 12 individual worms from a single flume (see Fig. 5). There was no significant relationship between the RGR of $S$. benedicti and the flux of suspended particulate nitrogen ( $p>0.6$ for each size class)

(2) the mechanics of particle capture were adversely affected by faster flows (i.e. suspension-feeding worms were less efficient at faster flows).

In this study, we tested those alternatives by manipulating the concentration of suspended food and flow speed independently. In particular, we were able to create similar fluxes of suspended food by 2 different mechanisms. For example, the fluxes in the high-food, $3 \mathrm{~cm} \mathrm{~s}^{-1}$, treatment and the fluxes in the low-food, $6 \mathrm{~cm} \mathrm{~s}^{-1}$, treatment ranged between 2 to $4 \mathrm{mg} \mathrm{N} \mathrm{cm}^{-2}$ $\mathrm{h}^{-1}$ (Fig. 4). The similar growth rates of Polydora cornuta in these treatments indicates that the flux of suspended food is a key factor influencing this species' growth rate, regardless of whether the flux is altered by flow speed or by the concentration of suspended food particles (Fig. 4). Bock \& Miller (1996) manipulated flow speed and the amount of particles in suspension and concluded that the flux of high-quality suspended particles was a good predictor of the amount of time interface-feeding polychaetes devoted to suspension feeding, regardless of whether the flux was altered by the concentration of seston or by the 
flow speed. Our experiment suggests that the behavioral response of interface feeders to a flux of highquality suspended food leads to enhanced nutrition and growth, as one would expect.

In general, the relative growth rates (RGR) of Polydora cornuta in the present study corresponded very closely to those measured by Hentschel (2004), but the data for Streblospio benedicti disagree with those of Hentschel (2004). In the present study, the RGR of $S$. benedicti was quite variable and showed no significant relationship to either flow speed, the concentration of suspended microalgae, or the flux of suspended food (Figs. $5 \& 6$ ). In fact, the only trend that approached significance at $\alpha=0.05$ was that the RGR of small $S$. benedicti declined slightly as flow increased in the low-food concentration (Fig. 5A). The data suggest that faster flows might have inhibited suspension feeding activity (e.g. Levinton 1991) or rates of successful particle capture by $S$. benedicti (Patterson 1991, Shimeta \& Jumars 1991, Eckman \& Duggins 1993, Shimeta \& Koehl 1997). As in any experiment, caution is required when extrapolating beyond the conditions we tested (i.e. the velocities and food concentrations).

We designed our experiment to measure growth rates because growth is the most integrative measure of a juvenile's nutritional gains from feeding. The growth-rate data suggest that interface-feeding Polydora cornuta and Streblospio benedicti obtain the majority of their nutrition by different means. P. cornuta appears to benefit greatly from conditions that favor prolonged periods of suspension feeding (i.e. a sustained flux of suspended food particles), while $S$. benedicti does not seem to rely as much on suspended food resources. We do note, however, that the relative growth rates measured in all of the flows between 3 to $12 \mathrm{~cm} \mathrm{~s}^{-1}$ are much faster than those reported for still-water $S$. benedicti cultures fed saltmarsh mud (Bridges et al. 1994).

The different growth responses of Polydora cornuta and Streblospio benedicti we measured in relation to flow and the flux of suspended food particles are consistent with the distributions of these 2 species in estuarine habitats. $S$. benedicti is more common than $P$. cornuta in muddier sediments, where flows tend to be slower and there probably is not much benefit associated with prolonged periods of suspension feeding instead of deposit feeding on organic-rich mud. In places where the 2 species are abundant and intermingled, such as the site where we collected specimens, differences in flow-dependent feeding behavior might reduce interspecific competition (e.g. Levin 1981). Based on the extremely rapid growth rates we measured for $P$. cornuta, we predict it will be the competitively dominant species in places where faster flows tend to occur. Temporal variability in flow and the flux of suspended food particles (e.g. due to storms or the lunar tidal cycle) is also likely to benefit $P$. cornuta much more than $S$. benedicti.

More generally, the growth-rate data from different flow regimes have several implications for the dynamics of spionid populations and the communities in which they are often abundant and important members (e.g. Noji \& Noji 1991, Cummings et al. 1996, Stehlik \& Meise 2000, Bolam \& Fernandes 2002, 2003). Several authors have developed demographic models of spionid populations that point to juvenile growth rate as a central parameter (e.g. Levin \& Huggett 1990, Zajac 1991a,b, Levin et al. 1996). Because these models were based, in part, on rates of juvenile growth and development measured in still-water laboratory experiments, the number of individuals in a spionid population that feeds like Polydora cornuta is likely to increase much more rapidly in nature, where some flow and flux of suspended food always occurs. Even Streblospio benedicti grows much more rapidly in flows that resuspend sediment than in still water (Hentschel 2004). Given the strong influence that flow has on the growth rates of juveniles, it seems likely that egg production by adults will also vary with hydrodynamic conditions. If flow enhances juvenile growth and adult reproduction, spionid densities might increase rapidly in certain flow regimes. Dense patches of spionids can exclude other species, including commercially important bivalves (Bolam \& Fernandes 2003). Spionids also are common items in the diets of fishes and shorebirds (e.g. Virnstein 1977, Zajac 1995, Stehlik \& Meise 2000, West et al. 2003), and this food resource for prominent vertebrates will, therefore, be enhanced greatly in places where or at times when hydrodynamic conditions favor the spionids' suspension feeding.

The short time scale (3 d) over which extensive growth occurred in our experiment is especially important for gauging the ecological effects of flow variability on spionid populations. For example, larvae recruiting to the benthos a few days before the maximal tidal exchange during a spring tide will probably grow more rapidly than will juveniles that recruit during neap tides. Similarly, larvae settling prior to a few days of storm activity will probably suspension feed more frequently (Bock \& Miller 1995) and grow more rapidly than will juveniles that settle prior to a few days of calm weather. Several studies have pointed to the early juvenile period as a possible bottleneck in the dynamics of benthic populations (e.g. Jumars et al. 1990, Hentschel \& Jumars 1994, Olafsson et al. 1994, Gosselin \& Qian 1997, Hunt \& Scheibling 1997, Hentschel 1998a,b); even a few days of favorable flow might ease the transition from pelagic larva to benthic juvenile. The exact time scales will, of course, depend on how quickly recruits can suspension feed. Spionid larvae typically de- 
velop palps before settlement (e.g. Blake 1969), and $P$. cornuta juveniles $<1.5 \mathrm{~mm}$ in length have been observed to suspension feed $<2 \mathrm{~d}$ after swimming larvae settled in laboratory vials of sediment (B. T. Hentschel pers. obs). Flow also varies spatially on a range of scales, and efforts to understand the causes of spatial patchiness in soft-sediment communities will benefit from characterization of the hydrodynamic conditions inside and outside of dense spionid patches.

Although our measurements of growth rates in different flow regimes clarify the effects that suspension feeding in moderate flows can have on different spionid populations, the mechanisms that cause Polydora cornuta to benefit more from suspension feeding than does Streblospio benedicti are speculative at this time. The morphology of $P$. cornuta, which has much longer palps than $S$. benedicti, probably provides advantages during suspension feeding. In particular, P. cornuta typically coils or arches its palps above the sediment (e.g. Taghon et al. 1980), while $S$. benedicti typically extends its short palps into the benthic boundary layer at a single angle (e.g. Dauer et al. 1981). These different geometries might alter the rates at which particles are contacted in a turbulent boundary layer and the rates at which contacted particles are retained during transport along a worm's palps (Shimeta \& Jumars 1991, Shimeta \& Koehl 1997). Recent measurements of particle contact and retention by juvenile $P$. cornuta show that retention is highly variable and can be enhanced when worms have been starved (Shimeta et al. 2004). The rates of particle contact and retention of $S$. benedicti have not been studied in relation to flow speed, but our growth-rate data suggest that $S$. benedicti might have reduced retention in faster flows relative to $P$. cornuta. It also is possible that these interfacefeeding spionids will show reduced particle capture and growth at flows faster than those in our experiment, as has been shown for some bivalves and other obligate suspension feeders (e.g. Okamura 1985, Wildish et al. 1987, 1992, Wildish \& Miyares 1990, Eckman \& Duggins 1993, Newell et al. 2001, Ackerman \& Nishizaki 2004).

Ultimately, a mechanistic understanding of why the growth rates of Polydora cornuta and Streblospio benedicti responded very differently to changes in the flux of suspended food will require experiments that simultaneously measure rates of feeding activity, particle capture, and growth in different flow regimes. Such comparative data are very difficult to obtain in a single controlled experiment due to the small size of juvenile spionids and the operational constraints associated with different flume designs. For example, the large annular flumes used in our experiment are well suited for creating hydrodynamically distinct mesocosms for several days, but the rotating top plate that drives the flow pre- cludes downward-looking observations of feeding behavior (e.g. Taghon \& Greene 1992) and the sampling of deposited material, including feces to measure feeding rates (e.g. Forbes \& Lopez 1990), without stopping the flow. Smaller pump-driven flumes that are well suited for making high-magnification video observations of particle capture by individual worms (e.g. Shimeta \& Koehl 1997, Shimeta et al. 2004) do not facilitate measuring the growth of dozens of worms simultaneously. To date, only Taghon (1992) and Taghon \& Greene (1992) have measured rates of feeding and growth simultaneously in different flow speeds. Those experiments were, unfortunately, complicated by low concentrations of suspended food particles, and the growth rates measured were 4 to $5 \times$ lower than those in this study and in Hentschel (2004), where microalgae were added to the water column to create natural concentrations of particulate nitrogen. In situ manipulations of flow (e.g. Judge et al. 1992, Powers \& Peterson 2000) have great promise for reducing some of the artifacts associated with laboratory flumes, but simultaneous observations of the rates of growth and feeding will be impossible in most field settings. A mechanistic understanding of how flow and the flux of suspended food affect interface-feeding benthos remains incomplete, but it is clear that the relationships between feeding behaviors and the distributions of benthic populations and communities in time and space cannot be understood without considering the effects of flow on interfacefeeding populations.

Acknowledgements. C. Fuller and P. Nawrot provided expert technical assistance at the Rutgers University Flume Facility. Discussions with G. Taghon, J. Shimeta, J. P. Grassle, and K. Stocks improved the design of experiments and interpretation of the data. J. F. Grassle generously provided access to videomicroscopy equipment in his lab, and J. Gregg assisted in the image analysis of worm body-size measurements. Comments by B. Herrick, and 4 anonymous reviewers improved earlier versions of this manuscript. Financial support was provided by NSF grant OCE-0000951.

\section{LITERATURE CITED}

Ackerman JD, Nishizaki MT (2004) The effect of velocity on the suspension feeding and growth of the marine mussels Mytilus trossulus and M. californianus: implications for niche separation. J Mar Syst 49:195-207

Aller RC (1982) The effects of macrobenthos on chemical properties of marine sediment and overlying water. In: McCall PL, Tevesz MJS (eds) Animal-sediment relations. Plenum, New York, p 53-102

Aller RC, Yingst JY (1985) Effects of marine deposit-feeders Heteromastus filiformis (Polychaeta), Macoma balthica (Bivalvia), and Tellina texana (Bivalvia) on averaged sedimentary solute transport, reaction rates, and microbial distributions. J Mar Res 43:615-645

Blake JA (1969) Reproduction and larval development of Polydora from northern New England. Ophelia 7:1-63 
Bock MJ, Miller DC (1995) Storm effects on particulate food resources on an intertidal sandflat. J Exp Mar Biol Ecol 187:81-101

Bock MJ, Miller DC (1996) Fluid flow and suspended particulates as determinants of polychaete feeding behavior. J Mar Res 54:565-588

Bock MJ, Miller DC (1997) Particle-bound organic matter as a cue for suspension feeding in tentaculate polychaetes. J Exp Mar Biol Ecol 215:65-80

Bolam SG, Fernandes TF (2002) Dense aggregations of tubebuilding polychaetes: response to small-scale disturbances. J Exp Mar Biol Ecol 269:197-222

Bolam SG, Fernandes TF (2003) Dense aggregations of Pygospio elegans (Claparede): effect on macrofaunal community structure and sediments. J Sea Res 49:171-185

Brafield AE, Newell GE (1961) The behaviour of Macoma balthica (L.). J Mar Biol Assoc UK 41:81-87

Bridges TS, Levin LA, Cabrera D, Plaia G (1994) Effects of sediment amended with sewage, algae, or hydrocarbons on growth and reproduction in two opportunistic polychaetes. J Exp Mar Biol Ecol 177:99-119

Cummings VJ, Pridmore RD, Thrush SF, Hewitt JE (1996) Effect of the spionid polychaete Boccardia syrtis on the distribution and survival of juvenile Macomona liliana (Bivalvia: Tellinacea). Mar Biol 126:91-98

Dauer DM, Maybury CA, Ewing RM (1981) Feeding behavior and general ecology of several spionid polychaetes from the Chesapeake Bay. J Exp Mar Biol Ecol 54:21-38

Eckman JE, Duggins DO (1993) Effects of flow speed on growth of benthic suspension feeders. Biol Bull 185:28-41

Fauchald K, Jumars PA (1979) The diet of worms: a study of polychaete feeding guilds. Oceanogr Mar Biol Annu Rev $17: 193-284$

Fisher RA (1920) Some remarks on the methods formulated in a recent article on 'The quantitative analysis of plant growth.' Ann Appl Biol 7:367-372

Forbes TL, Lopez GR (1990) Ontogenetic changes in individual growth and egestion rates in the deposit-feeding polychaete Capitella sp. I. J Exp Mar Biol Ecol 143:209-220

Frechette M, Butman CA, Geyer WR (1989) The importance of boundary-layer flows in supplying phytoplankton to the benthic suspension feeder Mytilus edulis L. Limnol Oceanogr 34:19-36

Gosselin LA, Qian PY (1997) Juvenile mortality in benthic marine invertebrates. Mar Ecol Prog Ser 146:265-282

Hentschel BT (1998a) Intraspecific variations in $\delta^{13} \mathrm{C}$ indicate ontogenetic diet changes in deposit-feeding polychaetes. Ecology 79:1357-1370

Hentschel BT (1998b) Spectrofluorometric quantification of neutral and polar lipids suggests a food-related recruitment bottleneck for juveniles of a deposit-feeding polychaete population. Limnol Oceanogr 43:543-549

Hentschel BT (2004) Sediment resuspension and boundarylayer flow dramatically enhance the growth rates of interface-feeding spionid polychaetes. J Mar Syst 49:209-224

Hentschel BT, Jumars PA (1994) In situ chemical inhibition of benthic diatom growth affects recruitment of competing, permanent and temporary meiofauna. Limnol Oceanogr 39:816- 838

Hunt HL (2004) Effects of epibenthic predators in flow: transport and mortality of juveniles of the soft shell clam Mya arenaria. Mar Ecol Prog Ser 279:151-160

Hunt HL, Scheibling RE (1997) Role of early post-settlement mortality in the recruitment of benthic marine invertebrates. Mar Ecol Prog Ser 155:269-301

Hunt OD (1925) The food of bottom fauna of the Plymouth fishing grounds. J Mar Biol Assoc UK 13:560-599
Hurlbert SH (1984) Pseudoreplication and the design of ecological field experiments. Ecol Monogr 54:187-211

Judge ML, Coen LD, Heck KL Jr. (1992) The effect of longterm alteration of in situ currents on the growth of Mercenaria mercenaria in the northern Gulf of Mexico. Limnol Oceanogr 37:1550-1559

Jumars PA, Mayer LM, Deming JW, Baross JA, Wheatcroft RA (1990) Deep-sea deposit-feeding strategies suggested by environmental and feeding constraints. Phil Trans R Soc Lond Ser A 331:85-101

Lenihan HS, Peterson CH, Allen JM (1996) Does flow speed also have a direct effect on growth of active suspensionfeeders: an experimental test on oysters. Limnol Oceanogr 41:1359-1366

Levin LA (1981) Dispersion, feeding behavior and competition in two spionid polychaetes. J Mar Res 39:99-117

Levin L, Caswell H, Bridges T, DiBacco C, Cabrera D, Plaia G (1996) Demographic responses of estuarine polychaetes to pollutants: life table response experiments. Ecol Appl 6: 1295-1313

Levin LA, Huggett DV (1990) Implications of alternative reproductive modes for seasonality and demography in an estuarine polychaete. Ecology 71:2191-2208

Levinton JS (1971) Control of tellinacean (Mollusca: Bivalvia) feeding behavior by predation. Limnol Oceanogr 16: 660-662

Levinton JS (1991) Variable feeding behavior in three species of Macoma (Bivalvia: Tellinacea) as a response to water flow and sediment transport. Mar Biol 110:375-383

Lindsay SM, Woodin SA (1995) Tissue loss induces switching of feeding mode in spionid polychaetes. Mar Ecol Prog Ser 125:159-169

Miller DC, Bock MJ, Turner EJ (1992) Deposit and suspension feeding in oscillatory flows and sediment fluxes. J Mar Res 50:489-520

Muschenheim DK (1987) The dynamics of near-bed seston flux and suspension-feeding benthos. J Mar Res 45: 473-496

Newell CR, Wildish DJ, MacDonald BA (2001) The effects of velocity and seston concentration on the exhalent siphon area, valve gape and filtration rate of the mussel Mytilus edulis. J Exp Mar Biol Ecol 262:91-111

Noji CIM, Noji TT (1991) Tube lawns of spionid polychaetes and their significance for recolonization of disturbed benthic substrates. A review. Meeresforschung 33:235-246

Okamura B (1985) The effects of ambient flow velocity, colony size, and upstream colonies on the feeding success of bryozoa. II. Conopeum reticulum (Linnaeus), an encrusting species. J Exp Mar Biol Ecol 89:69-80

Olafsson EB (1986) Density dependence in suspensionfeeding and deposit-feeding populations of the bivalve Macoma balthica: a field experiment. J Anim Ecol 55: 517-526

Olafsson EB, Peterson CH, Ambrose WG (1994) Does recruitment limitation structure populations and communities of macro-invertebrates in marine soft sediments: the relative significance of pre- and post-settlement processes. Oceanogr Mar Biol Annu Rev 32:65-109

Patterson MR (1991) The effects of flow on polyp-level prey capture in an octocoral, Alcyonium siderium. Biol Bull 180: 93-102

Powers SP, Peterson CH (2000) Conditional density dependence: the flow trigger to expression of density-dependent emigration in bay scallops. Limnol Oceanogr 45:727-732

Rhodes DC (1974) Organism-sediment relations on the muddy seafloor. Oceanogr Mar Biol Annu Rev 12:263-300

Shimeta J, Jumars PA (1991) Physical mechanisms and rates 
of particle capture by suspension feeders. Oceanogr Mar Biol Annu Rev 29:191-257

Shimeta J, Koehl MAR (1997) Mechanisms of particle selection by tentaculate suspension feeders during encounter, retention, and handling. J Exp Mar Biol Ecol 209:47-73

Shimeta J, Witucki PF, Hippe KR (2004) Influences of nutritional state and temperature on suspension-feeding rates and mechanics in the spionid polychaete Polydora cornuta. Mar Ecol Prog Ser 280:173-180

Snelgrove PVR, Butman CA (1994) Animal-sediment relationships revisited: cause versus effect. Oceanogr Mar Biol Annu Rev 32:111-177

Stehlik LL, Meise CJ (2000) Diet of winter flounder in a New Jersey estuary: ontogenetic change and spatial variation. Estuaries 23:381-391

Stocks KI (2002) Flume experiment on post-settlement movement in polychaetes. J Mar Res 60:743-762

Taghon GL (1992) Effects of animal density and supply of deposited and suspended food particles on feeding, growth and small-scale distributions of two spionid polychaetes. J Exp Mar Biol Ecol 162:77-95

Taghon GL, Greene RR (1992) Utilization of deposited and suspended particulate matter by benthic 'interface' feeders. Limnol Oceanogr 37:1370-1391

Taghon GL, Nowell ARM, Jumars PA (1980) Induction of suspension feeding in spionid polychaetes by high particulate fluxes. Science 210:262-264

Thrush SF, Whitlatch RB, Pridmore RD, Hewitt JE, Cummings VJ, Wilkinson MR (1996). Scale-dependent recolonization: the role of sediment stability in a dynamic sandflat habitat.

Editorial responsibility: Otto Kinne (Editor-in-Chief), Oldendorf/Luhe, Germany
Ecology 77:2472-2487

Virnstein RW (1977) The importance of predation by crabs and fishes on benthic infauna in Chesapeake Bay. Ecology 58:1199-1217

West JM, Williams GD, Madon SP, Zedler JB (2003) Integrating spatial and temporal variability into the analysis of fish food web linkages in Tijuana Estuary. Environ Biol Fish 67:297-309

Wildish DJ, Miyares MP (1990) Filtration rate of blue mussels as a function of flow velocity: preliminary experiments. J Exp Mar Biol Ecol 142:213-219

Wildish DJ, Kristmanson DD, Hoar RL, DeCoste AM, McCormick SD, White AW (1987) Giant scallop feeding and growth responses to flow. J Exp Mar Biol Ecol 113: 207-220

Wildish DJ, Kristmanson DD, Saulnier (1992) Interactive effect of velocity and seston concentration on giant scallop feeding inhibition. J Exp Mar Biol Ecol 155:161-168

Zajac RN (1991a) Population ecology of Polydora ligni (Polychaeta: Spionidae) I. Seasonal variation in population characteristics and reproductive activity. Mar Ecol Prog Ser 77:197-206

Zajac RN (1991b) Population ecology of Polydora ligni (Polychaeta: Spionidae) II. Seasonal demographic variation and its potential impact on life history evolution. Mar Ecol Prog Ser 77:207-220

Zajac RN (1995) Sublethal predation on Polydora cornuta (Polychaeta: Spionidae): patterns of tissue loss in a field population, predator functional response and potential demographic impacts. Mar Biol 123:531-541

Submitted: October 11, 2004; Accepted: February 17, 2005

Proofs received from author(s): May 12, 2005 